\title{
NIGHTMARES FROM TOPICAL TIMOLOL EYE DROPS: A CASE REPORT
}

\section{Yousaf Jamal Mahsood ${ }^{\boxplus}$, Saima Farooq'}

\begin{abstract}
Topical timolol eyedrops are frequently used as medical treatment of glaucoma. They decrease the production of aqueous humor by blocking the beta adrenergic receptors of ciliary body. Although systemic absorption of eyedrops is negligible, still it can cause some serious side effects like bradycardia, heart block, bronchospasm, confusion and hypotension. We present a case who developed nightmares with use of topical beta-blockers. He was a chronic case of primary open angle glaucoma whose target intraocular pressure (IOP) couldn't be achieved with latanoprost alone, the first line drug, so we put him on topical timolol twice daily dosage to further decrease the IOP. On his follow-up visit he complained about bad dreams since starting timolol eye drops. This case report will add to the list of already known other side effects of timolol usage in glaucoma patients.
\end{abstract}

KEY WORDS: Dreams (MeSH); Nightmares (MeSH); Timolol (MeSH); Ophthalmic Solutions (MeSH); Glaucoma (MeSH); Intraocular Pressure (MeSH).

THIS ARTICLE MAY BE CITED AS: Mahsood YJ, Farooq S. Nightmares from topical timolol eye drops: A case report. Khyber Med Univ J 2020; I2(3):25I-2. DOI: 10.35845/kmuj.2020.20I58.

\section{INTRODUCTION}

$\mathrm{G}$ laucoma is a progressive optic neuropathy characterized by visual field loss and optic nerve changes. The main risk factor for this disease is raised intraocular pressure (IOP) and till date controlling IOP remains the only method to prevent further damage. ${ }^{1,2}$ We can control the IOP by medicines (topical eyedrops), lasers and surgically. As a first line medicine, topical prostaglandin analogues (PGA) are used because of its better efficacy, dosage and safety profile. However, sometimes mere PGA won't achieve the target and then we have to add topical betablockers (timolol). There are well known side effects of topical betablockers (BB) on many systems like nervous, gastrointestinal (GIT), cardiovascular (CVS), musculoskeletal, and respiratory. ${ }^{3}$

Here we describe a case of 65 years old male of glaucoma who had nightmares after starting topical timolol eyedrops.

\section{CASE REPORT}

A 65 years old male was referred to us by general ophthalmologist for treatment of his raised IOP. On presentation his IOP were $32 \mathrm{mmHg}$ both eyes and had changes on nerve fiber analysis and perimetry. We set a target IOP of $14 \mathrm{~mm} \mathrm{Hg}$, started him on topical PGA and advised him to come for follow-up after 4 weeks. After 4 weeks his IOP were down to $18 \mathrm{mmHg}$ but still above our target IOP level. So we added topical timolol eyedrops to further bring down the IOP and patient was asked to return in 2 weeks. The patient came one week before his appointment with the complaints that after starting timolol he is having nightmares which wake him up from the sleep. He couldn't recall the exact pattern of nightmares but according to him it was very bad. To confirm whether bad dreams were due to timolol we stopped timolol and started him on topical brinzolamide to keep the IOP in target range. Since timolol can be found in body tissues up to one month ${ }^{4}$ so we asked the patient to return after one month to allow it to wash out from body. When he returned after a month, his IOP were $14 \mathrm{mmHg}$ both eyes and was asked whether he is still experiencing nightmares. He
I. Department of Ophthalmology, Khyber Girls Medical College, Hayatabad Medical Complex, Peshawar, Pakistan Email凶:yousaf82@hotmail.com Contact \#: +92-333-9102980

$\begin{array}{ll}\text { Date Submitted: } & \text { March 03, 2020 } \\ \text { Date Revised: } & \text { April 04, 2020 } \\ \text { Date Accepted: } & \text { July 18, 2020 }\end{array}$

responded in negative and said that from the day timolol was stopped he has not experienced bad dreams. This case reports bad dreams/nightmares as a rare side effect of topical timolol eyedrops.

\section{DISCUSSION}

Timolol is a very effective drug in treatment of glaucoma and it can decrease the IOP by about $20 \%$ from baseline. There are reports about side effects with topical timolol administration which range from local effects to other systems of the body. ${ }^{3}$ In nervous system depression, psychosis and few cases of hallucinations are already reported as side effects of topical timolol eyedrops use. ${ }^{5}$ However, nightmares or bad dreams are not its well-known side effects as what we saw in our case. While doing literature search we found that in 1992 Jane Mort $^{6}$ and then Negi A et $\mathrm{al}^{7}$ in 2000 reported similar cases who started seeing nightmares after put on timolol for treating glaucoma. The nightmares were no more present as soon timolol was taken off.

The brain contains $B$, receptors and this may be the reason that some patients who use beta-blockers experience psychiatric effects. ${ }^{8-10}$ Since the elimination of beta-blockers from the body takes longer in older people, this may be the reason that nightmares or bad dreams occurred in elderly. There are methods to reduce the systemic absorption of topical eyedrops like punctal occlusion or eyelids closure for 3 minutes and this may result in reduced occurrence of this side effect. 
We recommend that ophthalmologists should be aware of this rare side effect when prescribing topical beta-blockers to elderly patient and they should educate their patients on proper techniques of punctal occlusion.

\section{REFERENCES}

I. Heijl A, Leske MC, Bengtsson B, Hyman L, Bengtsson B, Hussein M, et al. Reduction of intraocular pressure and glaucoma progression: results from Early Manifest Glaucoma Trial. Arch Ophthalmol 2002; I 20(10): | 268-79. DOI: 10.1001/archopht. 120.10.1268.

2. Leske MC, Heijl A, Hussein M, Bengtsson B, Hyman L, Komarrof E, et al. Factors for glaucoma progression and the effect of treatment: the Early Manifest Glaucoma Trial. Arch Ophthalmol 2003; I I (I):48-56. DOI: 10.100I/ archopht. I21.I.48.

3. Zimmerman TJ, Baumann JD, Hetherington J. Side effects of timolol. Surv Ophthalmol 1983;28:243-5I. DOI: 10.1016/ 0039-6257(83)90।40-6.

4. Trope GE, Clark BA. Beta adrenergic receptors in pigmented ciliary processes. $\mathrm{Br} J$ Ophthalmol 1982;66(I2):788-92. DOI: 10.1 | 36/ bjo.66.12.788.

5. Nanda T, Rasool N, Callahan AB, Stamper RL, Odel JG. Ophthalmic Timolol Hallucinations: A Case Series and Review of the Literature. J Glaucoma 2017;26(9):e2।4-6. DOI: I0.1097/IJG.0000000 000000712 .

6. Mort JR. Nightmare Cessation Following Alteration of Ophthalmic Administration of a Cholinergic and a Beta-Blocking Agent. Ann
Pharmacother 1992. 26:914-6. DOI: I0.1/77//0600280920 2600709.

7. Negi A, Thoung D, Dabbous $F$. Nightmares with topical betablocker. Eye (Lond) 2000; I4(5): 8I3-4. DOI: 10.1038/eye. 2000. 225.

8. Munroe WP, Rindone JP, Kershner RM. Systemic side effects associated with the ophthalmic administration of timolol. Drug Intell Clin Pharm 1985; 19:85-9. DOI: I0.1 177// 0600 280850190020I.

9. Akingbehin T, Sunder P. Ophthalmic topical beta blockers: review of ocular and systemic adverse effects. J Toxicol Cutan Ocul Toxicol 1990;9:131-7

10. Lesar TS. Comparison of ophthalmic blocking agents. Clin Pharm 1987;6:45 I-63.

\section{AUTHORS' CONTRIBUTIONS}

Following authors have made substantial contributions to the manuscript as under:

YJM: Diagnosis and management of case, critical review, final approval of the version to be published

SF: Identification of case, drafting the manuscript, final approval of the version to be published

Authors agree to be accountable for all aspects of the work in ensuring that questions related to the accuracy or integrity of any part of the work are appropriately investigated and resolved.

\begin{tabular}{|c|}
\hline CONFLICT OF INTEREST \\
Authors declared no conflict of interest \\
FINANCIAL DISCLOSURE \\
NIL
\end{tabular}

\section{DATA SHARING STATEMENT}

The data that support the findings of this study are available from the corresponding author upon reasonable request

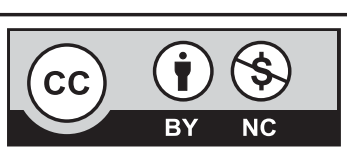

This is an Open Access article distributed under the terms of the Creative Commons Attribution-Non Commercial 2.0 Generic License.
KMUJ web address: www.kmuj.kmu.edu.pk

Email address: kmuj@kmu.edu.pk 